\title{
Nitrogen and Phosphorus Dynamics in the Biofloc Production of the Pacific White Shrimp, Litopenaeus vannamei
}

\author{
Kassio Rios DA Silva \\ Institute of Oceanography, Federal University of Rio Grande - FURG, Av. Itália, km 08, \\ Carreiros, Rio Grande, RS 96201-900, Brazil \\ Wilson Wasielesky Jr. ${ }^{1}$ and Paulo CÉsar Abreu \\ Aquaculture and Marine Biotechnology Group, Institute of Oceanography, Federal University \\ of Rio Grande - FURG, Av. Itália, km 08, Carreiros, Rio Grande, RS 96201-900, Brazil
}

\begin{abstract}
A study evaluating nitrogen and phosphorus dynamics was carried out using biofloc technology (BFT) systems employed to raise Litopenaeus vannamei juveniles. The study was carried out for 42 d in three fiberglass tanks with $210 \mathrm{~L}$ useful volume with no water exchange. Salinity, temperature, dissolved oxygen, pH, nutrients, suspended solids, and chlorophyll- $a$ were monitored every 3 d. At the completion of the experiment, the shrimp had absorbed 39.1 and $35.0 \%$ of the total nitrogen $(\mathrm{N})$ and phosphorus (P) inputs, respectively, while $39.0 \%$ of the $N$ and $34.1 \%$ of the $P$ remained in the system in dissolved forms. The dominant process of ammonium immobilization in the system was oxidation by nitrifying bacteria. On Day 42, the nitrate concentration represented more than $80 \%$ of the total dissolved inorganic nitrogen in all tanks. However, most of the dissolved nitrogen present in the tanks $(80 \%)$ was organic. Phosphate and organic nitrogen and phosphorus continuously accumulated in the system throughout the experiment. The removal of these nutrients should be the focus of future studies because they may enhance the growth of harmful algae in tanks and in the water bodies that collect the post-crop wastewater.
\end{abstract}

World aquaculture production has grown by approximately $8.3 \%$ per year from 1970 to 2008, reaching a production of 52.5 million tons. This represents $36.9 \%$ of the total worldwide captured fish production (FAO 2010). Shrimp culture has also seen a significant expansion worldwide, contributing to the world's aquaculture production, but concerns about the environmental impacts of this activity have also increased (Tovar et al. 2000; Jory et al. 2001).

The main environmental impacts of aquaculture activity are often identified as effluent loading and the eutrophication of adjacent water bodies, the introduction of exotic species and the overuse of fish meal in commercial feed (Naylor et al. 2000; Avnimelech 2006; Lacerda et al. 2006; Sena et al. 2006). Extensive water

\footnotetext{
${ }^{1}$ Corresponding author.
}

exchange is routinely performed by shrimp farmers to ensure satisfactory water quality, resulting in a significant input of nutrients and organic matter into the surrounding environment (Boyd and Clay 1998; Lacerda et al. 2006). The effluent from crops can contribute to the eutrophication of aquatic environments in two ways: (1) by directly adding organic matter and/or (2) by stimulating primary production due to the input of dissolved inorganic $\mathrm{N}$ and $\mathrm{P}$ (Thoman et al. 2001). Environmental and biosecurity concerns demand alternative systems that ensure high productivity, low risk of contamination, and minimal environmental impact.

A feasible alternative to avoid eutrophication and disease transmission is to reduce effluent dumping (Thoman et al. 2001) using rearing systems with no or minimal water exchange, such as the biofloc technology (BFT) culture system. In this system, the $\mathrm{C}: \mathrm{N}$ ratio is 
increased by adding a carbon source to promote the assimilation of nitrogen (mainly ammonium) by heterotrophic bacteria and enhance biofloc formation, which contribute to penaeid shrimp nutrition (Avnimelech 1999; Tacon et al. 2002; Burford et al. 2003, Burford et al. 2004; Avnimelech 2006; Ebeling et al. 2006). Among the foremost advantages of this system are the ease in implementing biosafety strategies (Moss 1999), the reduction of dietary protein (Burford et al. 2004; Ballester et al. 2010), and the reduction or elimination of the environmental impact caused by effluents (Browdy et al. 2001). However, despite the advantages offered by BFT systems, they require a high stocking density ( $>200 \mathrm{shrimp} / \mathrm{m}^{2}$ ) to ensure economic viability (Weirich et al. 2002).

Phosphorus levels in most commercial diets are above the nutritional requirements of raised organisms or are present in unavailable forms (Kibria et al. 1996; Montoya et al. 2000). Similarly, commercial feed contains high protein levels to fulfill the essential amino acid and energy needs of cultured shrimp (Ballester et al. 2010). Therefore, dissolved nitrogen, especially ammonia and phosphorus (phosphate), are largely produced in intensive shrimp cultures due to excretion and decomposition of uneaten feed. Ammonia, the most toxic nitrogen form to shrimp, is mobilized by different pathways such as nitrification, assimilation by photoautotrophic and heterotrophic microorganisms or is lost to the atmosphere due to the volatilization of gaseous ammonia. Unlike ammonia, phosphate is not lost to the atmosphere and is usually removed from the water by phytoplankton or chemical/biological processes occurring in the sediment.

Nutrient dynamics in the system may have a great impact on cultured shrimp because of the presence of toxic nitrogen elements (ammonia and nitrite) or the growth of undesirable harmful microorganisms caused by increased nutrient concentration or imbalanced $\mathrm{N}: \mathrm{P}$ ratios. Thus, understanding nutrient cycling processes in BFT compartments is important for developing nutrient removal strategies. Nutrient dynamics have been evaluated in semi-intensive (Páez-Osuna et al. 1997) and intensive (Jackson et al. 2003) shrimp culture systems in earthen ponds, but little is known about nutrient dynamics in BFT systems using tanks with no sediment. Therefore, this study aims to characterize the routes of removal and transfer of nitrogen and phosphorus fractions in a super-intensive BFT system during the rearing of Pacific white shrimp, Litopenaeus vannamei. The study considered feed and sugar cane molasses as the only $\mathrm{N}$ and $\mathrm{P}$ inputs and analyzed nitrogen and phosphorus dynamics in the different compartments (shrimp, water, and particles) and forms (organic and inorganic) found in this rearing system.

\section{Material and Methods}

\section{Experimental Design}

The experimental timeframe was $42 \mathrm{~d}$ and was conducted in a greenhouse at the Federal University of Rio Grande - FURG Marine Aquaculture Station (EMA/FURG), Southern Brazil $\left(32^{\circ} 12^{\prime} \mathrm{S}\right.$ and $\left.51^{\circ} 50^{\prime} \mathrm{W}\right)$. The experimental units were three circular, fiberglass tanks (310 $\mathrm{L}$ total volume and $0.33 \mathrm{~m}^{2}$ of bottom area) with no water exchange. The tanks were filled with $210 \mathrm{~L}$ of filtered seawater (salinity 30 ppt) and aerated uniformly to avoid particle sedimentation. Water temperature was maintained with the aid of electric heaters. Water level and salinity were maintained throughout the experiment by adding dechlorinated freshwater. All tanks were stocked with $300 \mathrm{shrimp} / \mathrm{m}^{2}$ $(0.12 \pm 0.02 \mathrm{~g}$ mean weight $\pm \mathrm{SD})$ post-larvae from the EMA/FURG hatchery. Shrimp feed containing 38\% crude protein (Poty Mar@), São Paulo, Brazil) was used throughout the experiment. The daily feeding rate for the shrimp was $10 \%$ of shrimp biomass; sinking feed was distributed evenly over the water surface twice a day at 0800 and $1900 \mathrm{~h}$.

Sugar cane molasses was used as a carbohydrate source to control ammonia. The amount of carbohydrate added was calculated as previously described by Avnimelech (1999) and was based on nitrogen feed inputs. Each time the total ammonium nitrogen (TAN) concentration rose above $0.6 \mathrm{mg} / \mathrm{L}$, an extra dose of molasses was added to the tanks to 
maintain the TAN levels within the security limits. The pre-weighed sugar cane molasses was mixed with water following the morning feed. Wheat bran and the diatom Thalassiosira weissflogii $\left(3 \times 10^{4}\right.$ cells/L) were added to the tanks to serve as bacterial substrates for biofloc formation. Shrimp were harvested $42 \mathrm{~d}$ after stocking. Individual wet weights and survival rates were recorded. Triplicate samples of sugar cane molasses, shrimp feed, wheat grain, and shrimp carcasses were analyzed for nitrogen and phosphorus content (AOAC 1995).

Temperature, salinity, $\mathrm{pH}$, and dissolved oxygen were monitored twice a day with an YSI 556 handheld multi-probe (Yellow Springs Instrument Company, Yellow Springs, $\mathrm{OH}$, USA).

\section{Water Samples}

Water samples were taken every $3 \mathrm{~d}$ to determine the levels of TAN, nitrite, nitrate, dissolved organic nitrogen (DON), particulate nitrogen (PN), total nitrogen (TN), orthophosphate, dissolved organic phosphorus (DOP), particulate phosphorus (PP), total phosphorus (TP), total suspended solids (TSS), and chlorophyll- $a($ Chl- $a)$.

Water samples were taken from the surface near the center of the tanks. The dissolved nitrogen and phosphorus were measured in water filtered through a $0.7 \mu \mathrm{m}$ nominal pore size glass fiber filter (Whatman GF/F). Accordingly, suspended solids were defined as the weight of the fraction retained in pre-washed, dried, and pre-weighed $0.7-\mu \mathrm{m}$ glass fiber filters. Filter weight measurements were conducted after the filters were maintained at $60 \mathrm{C}$ for $24 \mathrm{~h}$.

After collection, an unfiltered $200 \mathrm{~mL}$ aliquot and the filters containing particulate material was cooked with persulfate and frozen for subsequent TN, TP, PN, and PP analysis. The remaining sample was filtered using Whatman GF/F glass fiber filters for Chl- $a$ and dissolved nutrient analyses (nitrite, nitrate, TAN, and phosphate). The filtrates were immediately refrigerated for later analyses.

\section{Nutrient and Chlorophyll-a Analyses}

TAN was determined in triplicate immediately after sampling using the indophenol blue method (UNESCO 1983). Nitrite, nitrate, and phosphate were analyzed as described by Strickland and Parsons (1972). TN and TP were determined by persulfate digestion (Valderrama 1981), and PN and PP were determined through filter digestion (Valderrama 1981) in ultra-pure (Millipore Milli-Q, Billerica, MA, USA) water. DON and DOP concentrations were determined as follows: $\mathrm{DON}=\mathrm{TN}-\mathrm{PN}-$ Dissolved Inorganic Nitrogen (TAN + Nitrite + Nitrate), and $\mathrm{DOP}=\mathrm{TP}-\mathrm{PP}-$ Phosphate.

Chl- $a$ levels were determined fluorometrically using a calibrated Turner TD700 fluorometer (Turner Biosystems, Sunnyvale, CA, USA). The pigment was extracted at $-12 \mathrm{C}$ in the dark using $90 \% \mathrm{v} / \mathrm{v}$ acetone, and the concentration was determined as described by Welschmeyer (1994).

\section{Nitrogen and Phosphorus Dynamics}

For nitrogen and phosphorus budgets calculation, the system was divided into three main compartments: (1) a shrimp compartment, (2) a dissolved compartment, and (3) a particulate compartment (Fig. 1). Shrimp feed, sugar cane molasses, and stocked shrimp were considered as the only $\mathrm{N}$ and $\mathrm{P}$ inputs, and ammonia volatilization and denitrification were considered as the $\mathrm{N}$ outputs. The total wheat bran utilized represented $<0.2 \%$ of the total $\mathrm{N}$ and $\mathrm{P}$ inputs and were not accounted for the budget calculation. The phosphorus had no output route because there was no water renewal. The remaining $\mathrm{N}$ and $\mathrm{P}$ in the tanks were present in the shrimp biomass and in dissolved and particulate forms.

$$
\begin{aligned}
& \mathrm{N} \text { Inputs }=\mathrm{TN}(\text { final }- \text { initial }) \\
& +\mathrm{N} \text { in shrimp biomass }(\text { final }- \text { initial }) \\
& + \text { denitrification and ammonia } \\
& \text { volatilization }
\end{aligned}
$$




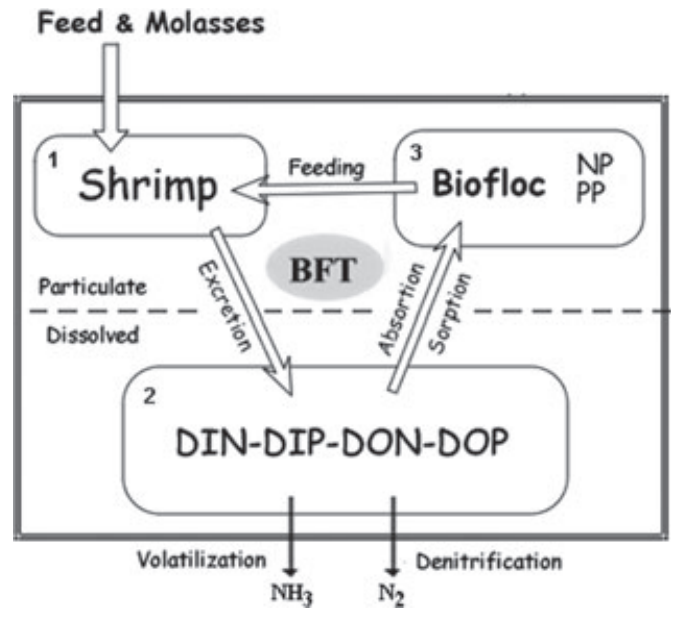

FIGURE 1. Model of nitrogen dynamics on BFT. Compartment 1 represents the amount of $N$ and $P$ retained in the shrimp biomass. Compartment 2 corresponds to the organic and inorganic nutrients dissolved in the rearing water. Compartment 3 shows the particulate $N$ and $P$ content.

$$
\begin{aligned}
& \text { P Inputs }=\mathrm{TP} \quad(\text { final }- \text { initial }) \\
& +\mathrm{P} \text { in shrimp biomass } \quad(\text { final }- \text { initial })
\end{aligned}
$$

\section{Results}

The average experimental water temperature was $27 \pm 2 \mathrm{C}$ (mean $\pm \mathrm{SD})$. The average salinity was $30.8 \pm 2 \mathrm{ppt}$, while the dissolved oxygen concentration ranged between 5.2 and $8.6 \mathrm{mg} / \mathrm{L}$. $\mathrm{pH}$ values decreased during the experiment with initial mean diurnal values of $8.76 \pm 0.33$, which dropped to $7.8 \pm 0.12$ at Day 42 .

Upon completion of the experiment, the survival rate was $90 \pm 5.4 \%$. The shrimp had a specific growth rate of $6.9 \% / \mathrm{d}$, reaching a final average weight of $2.17 \pm 0.5 \mathrm{~g}$. The apparent feed conversion ratio was $0.87 \pm 0.08$.

Chl- $a$ concentration decreased drastically in the initial $15 \mathrm{~d}$ due to phytoplankton die-off, probably caused by reduced light conditions (Fig. 2A). However, after the 18th d, there was an increase in the Chl- $a$ concentration up to 338 $\mu \mathrm{g} / \mathrm{L}$ at Day 42 , mainly due to the presence of cyanobacteria (data not show). TSS values increased considerably after Day 27. Mean TSS values were $350.3 \pm 116 \mathrm{mg} / \mathrm{L}$ (Fig. 2B).

The percentages of $\mathrm{N}$ found in each gram of feed and molasses were $6.09 \pm 0.45 \%$ and $0.8 \pm 0.02 \% \quad(n=3)$, respectively. Therefore, by the end of the experiment, there was an input of $11,603 \mathrm{mg}$ and $880 \mathrm{mg}$ of $\mathrm{N}$ due to the addition of feed and molasses, respectively. Similarly, the amounts of $\mathrm{P}$ found in feed and molasses were $0.8 \pm 0.01 \%$ and $0.06 \pm 0.007 \%(n=3)$, respectively, representing an addition of $1475 \mathrm{mg}$ and $48 \mathrm{mg}$ of $\mathrm{P}$, respectively, throughout the experiment. The shrimp contained $1.85 \pm 0.17 \%$ nitrogen and $0.18 \pm 0.008 \%$ phosphorus (a shrimp pool of each experimental unit was used for analysis; $n=3$ ). Therefore, the increase in shrimp biomass at the end of the experiment represented the incorporation of $4884 \mathrm{mg}$ of $\mathrm{N}$ and $534 \mathrm{mg}$ of $\mathrm{P}$.
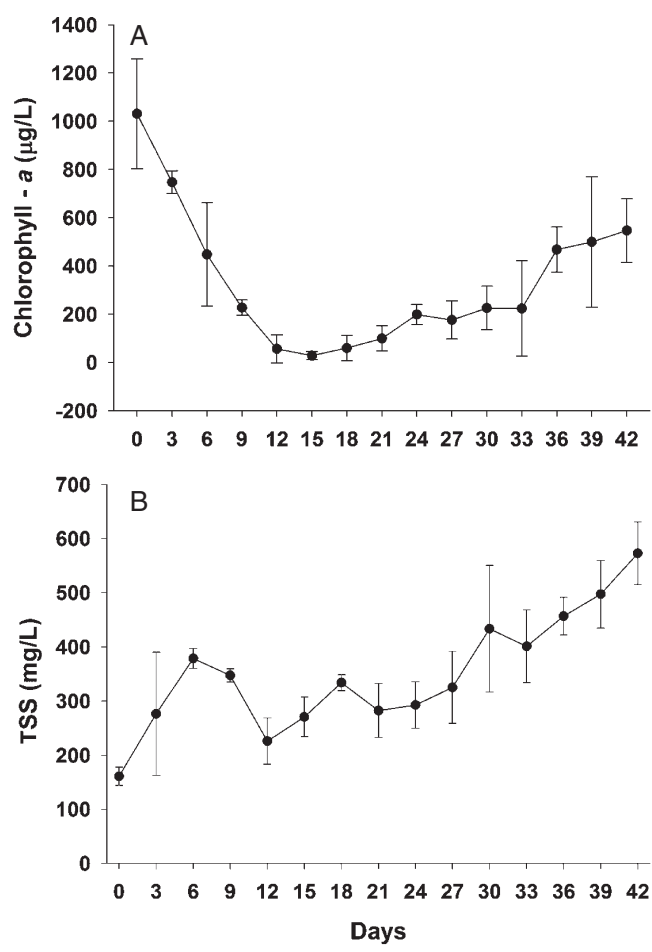

FIGURE 2. Variation in chlorophyll-a $(\mu \mathrm{g} / \mathrm{L})$ and total suspended solids $(\mathrm{mg} / \mathrm{L})$ average concentrations during the experiment. Error bars denote the SD. 
The ammonium concentration remained below $0.042 \mathrm{mg} \mathrm{N}-\mathrm{NH}_{4}+/ \mathrm{L}$ during the first 9 $\mathrm{d}$ of the experiment. After this period, the concentration increased until Day 18 (maximum value, $0.75 \mathrm{mg} / \mathrm{L}$ TAN) and then decreased until the end of the experiment (Fig. 3A). The substantial decrease of TAN on Day 21 occurred after the addition of extra sugar cane molasses. Nitrite and nitrate concentrations were low during the first $21 \mathrm{~d}$ (Fig. 3B, C). After Day 21, there was a considerable increase in concentration (maximum of $0.91 \pm 0.83$ $\mathrm{mg} / \mathrm{L} \mathrm{N}-\mathrm{NO}_{2}{ }^{-}$at Day 27 and $4.55 \pm 0.52$ $\mathrm{mg} / \mathrm{L} \mathrm{N}-\mathrm{NO}_{3}{ }^{-}$at Day 39) and a decrease in the TAN concentration.

The average PN concentration was 0.71 $\mathrm{mg} / \mathrm{L}$, with the highest concentrations observed in the first days of the experiment (Fig. 4A). DON concentrations were lower at the beginning of the experiment, and the highest value $(17.6 \mathrm{mg} / \mathrm{L})$ was observed at the end of the experiment (Fig. 4B). The amount of TN increased continuously throughout the experiment, with the highest values observed after Day 24. The mean $\mathrm{TN}$ value was $7.81 \pm 7.4$ $\mathrm{mg} / \mathrm{L}$.

All the phosphorus species analyzed increased as the shrimp grew and the feed input became more significant. Phosphate concentrations increased throughout the experiment, but especially after Day 21 (Fig. 5A). The lowest values were recorded at Day 0, and the highest were recorded at Day 42 $\left(1.38 \pm 0.06 \mathrm{mg} / \mathrm{L} \mathrm{P}-\mathrm{PO}_{4}{ }^{-3}\right)$. PP concentrations (Fig. 5B) ranged between 0.3 and 0.9 $\mathrm{mg} / \mathrm{L}$ until Day 36, when an increase was observed (maximum values $1.9 \mathrm{mg} / \mathrm{L}$ on Day 42). The mean PP value was $0.76 \pm 0.46 \mathrm{mg} / \mathrm{L}$. DOP concentrations (Fig. 5C) were below 0.31 $\mathrm{mg} / \mathrm{L}$ until Day 27, when a sevenfold increase was recorded (from 0.15 to $1.08 \mathrm{mg} / \mathrm{L}$ ). The highest DOP concentration occurred on Day 39 $(1.98 \pm 0.8 \mathrm{mg} / \mathrm{L})$. Likewise, TP concentrations rose consistently throughout the experiment, with the highest TP value $(4.6 \mathrm{mg} / \mathrm{L})$ measured on Day 42, and the lowest measured on Day 0.

The ratios between PN or PP and TSS were calculated to assess the amount of nitrogen and phosphorus retained in each gram of TSS
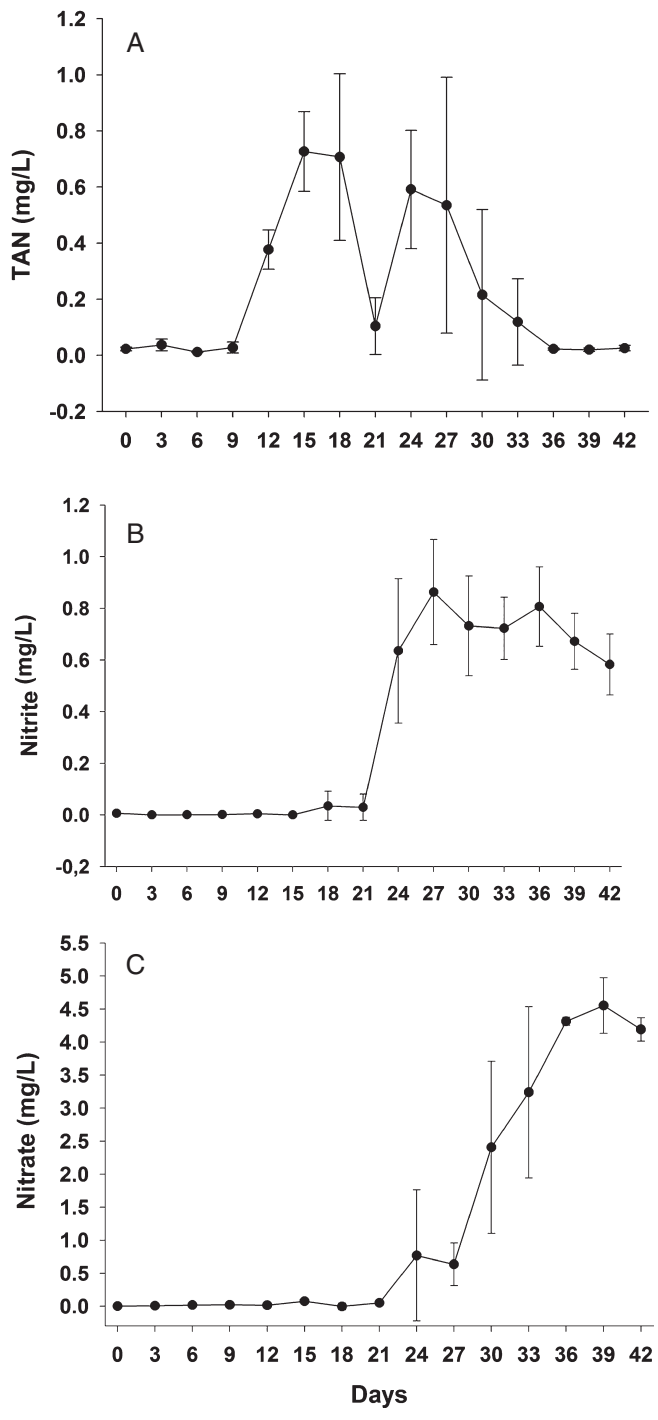

FIGURE 3. Variations in the average concentrations $(\mathrm{mg} / \mathrm{L})$ of $(A)$ total ammonium nitrogen, (B) nitrite, and $(C)$ nitrate during the experiment. Error bars denote the $S D$.

(Fig. 6). The PN/TSS ratio (w/w) (Fig. 6A) increased from Day 0, reaching 0.0035 on Day 9 , with minor variations until Day 21 . The ratio decreased after Day 24, reaching 0.004 on Day 36 . The ratio $(w / w)$ between PP and suspended solids slightly increased during the experiment, ranging between 0.0015 and 0.035 (Fig. 6B).

Approximately $80 \%$ of the estimated nitrogen input was trapped in the system (Fig. 7). 

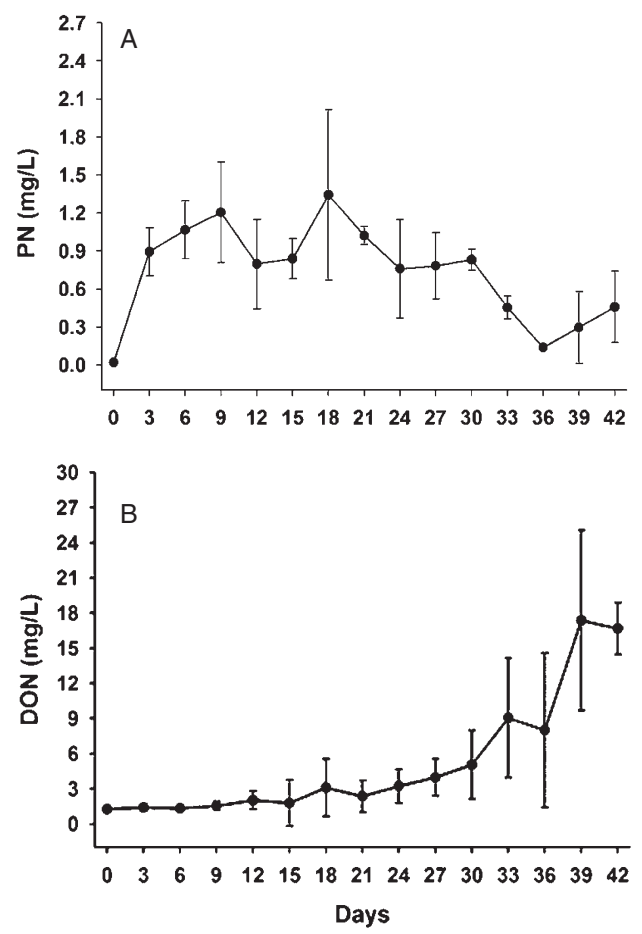

FIGURE 4. Variations in the average concentrations $(\mathrm{mg} / \mathrm{L})$ of $(A)$ particulate nitrogen and $(B)$ dissolved organic nitrogen during the experiment. Error bars denote the SD.

Almost 39\% of the nitrogen entering the system was retained in the dissolved compartment, with $31.25 \%$ as dissolved organic nitrogen (DON) and $7.7 \%$ as dissolved inorganic nitrogen (DIN) $\left(\mathrm{TAN}+\mathrm{NO}_{2}{ }^{-}+\mathrm{NO}_{3}{ }^{-}\right)$. Nitrate was the predominant inorganic nitrogen form, accounting for $87.1 \%$ of the DIN pool. Nitrite represented $12 \%$ and TAN represented $0.9 \%$ of the nitrogen input. Shrimp biomass corresponded to $39.13 \%$, while the particulate fraction (PN) accounted for only $1.4 \%$ of the TN input. Nitrogen loss due to denitrification and ammonia volatilization was estimated to be $20.55 \%$ of the $\mathrm{TN}$ added to tanks.

The dissolved compartment retained $34.1 \%$ of the TP input, with $50.7 \%$ in the form of phosphate and $49.3 \%$ as DOP (Fig. 8). The particulate pool (compartment 3) stored $26.5 \%$ and the shrimp biomass retained $35 \%$ of the total $\mathrm{P}$ added as feed and molasses. A small
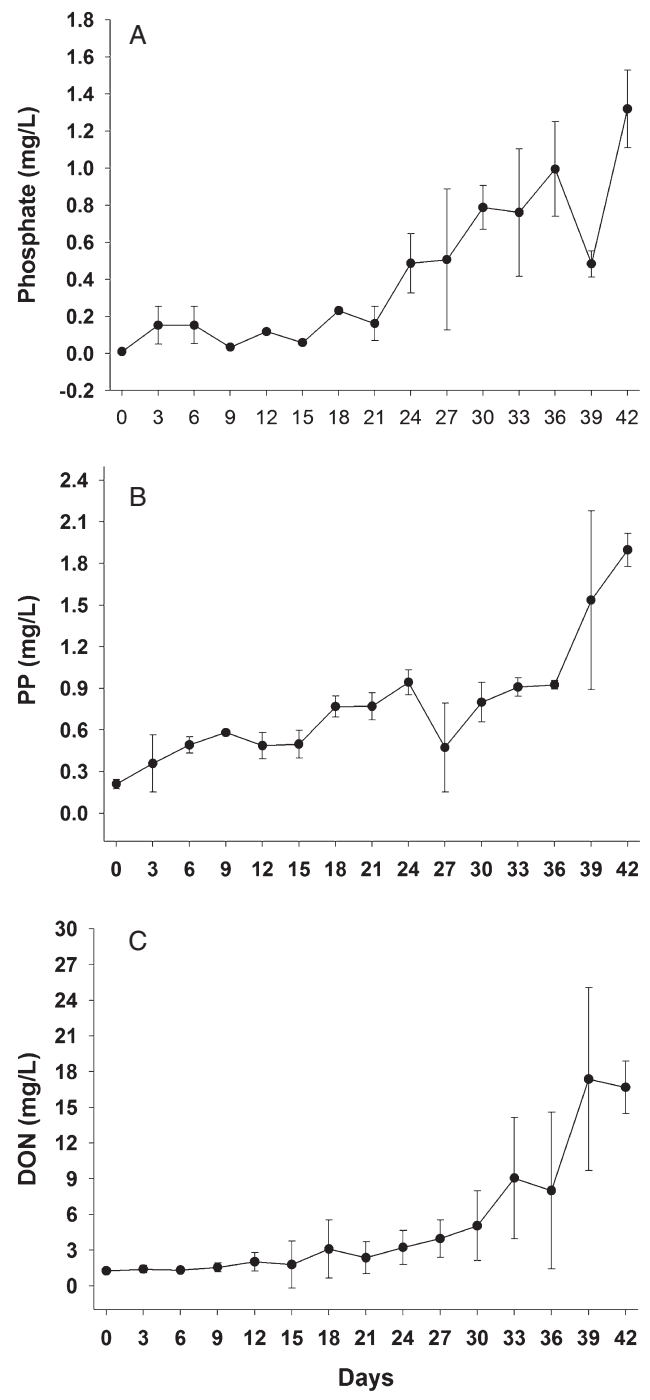

FIGURE 5. Variations in the average concentrations $(\mathrm{mg} / \mathrm{L})$ of $(\mathrm{A})$ orthophosphate, $(B)$ particulate phosphorus, and $(C)$ dissolved organic phosphorus during the experiment. Error bars denote the SD.

fraction $(4.5 \%)$ of added phosphorus was not detected in any of the compartments studied.

\section{Discussion}

The physical and chemical characteristics of the water analyzed throughout the experiment were within the acceptable limits established for the best growth conditions of L. vannamei (Wickins 1976; Van Wyk and Scarpa 1999). 

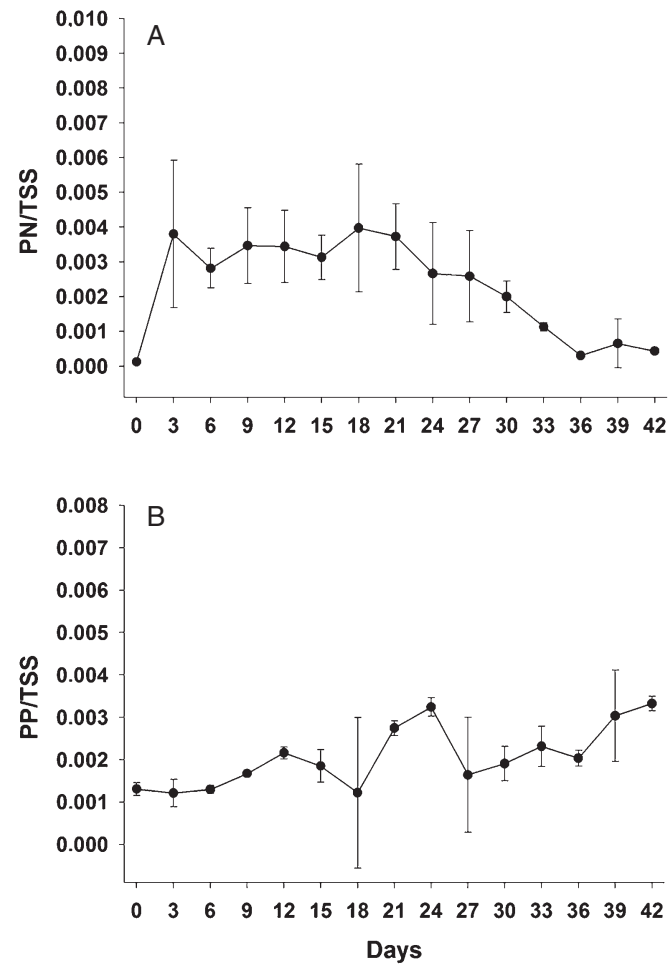

FIGURE 6. Variations in the (A) particulate nitrogen to suspended solids ratio and $(B)$ the particulate phosphorus to suspended solids ratio during the experiment. Error bars denote the $S D$.

These conditions, combined with the low TAN and complementary natural food, explain the satisfactory growth and survival obtained in this study. The low food conversion ratio obtained here $(0.87 \pm 0.08)$ may be explained by the consumption of natural microbiota present in the biofilm and bioflocs in the tanks, as observed previously (Abreu et al. 2007; Ballester et al. 2007; Silva et al. 2008). L. vannamei had a great capacity to incorporate the nitrogen and phosphorus added to the system during the study period. In this experiment, 39 and $35 \%$ of feed and molasses $\mathrm{N}$ and $\mathrm{P}$ inputs were retained in the shrimp biomass, respectively, which are much greater values than those obtained in other rearing systems in which the shrimp were stocked at lower densities (Robertson and Phillips 1995; Funge-Smith and Briggs 1998; Martin et al. 1998; Jackson et al. 2003).

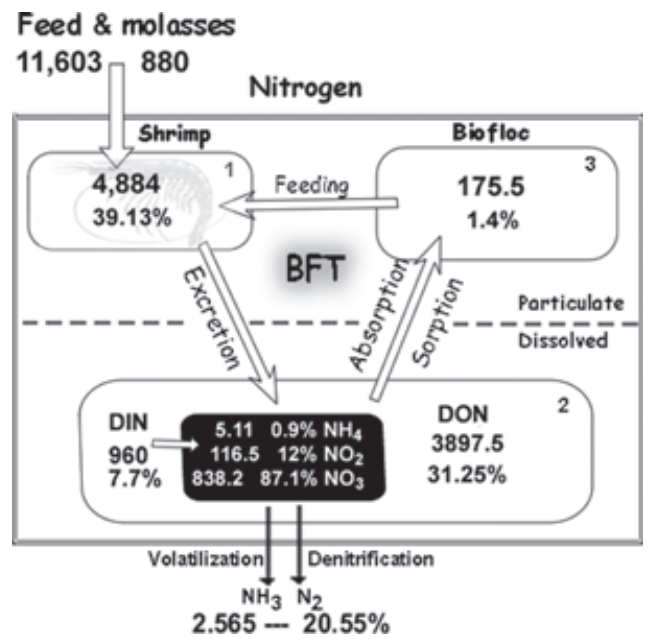

FIGURE 7. Nitrogen budget for Litopenaeus vannamei production. The inner boxes represent (1) the shrimp biomass, (2) the dissolved nitrogen pool, and (3) the particulate nitrogen pool (larger than $0.7 \mu \mathrm{m}$ ). Arrows leaving the main box represent denitrification and ammonia volatilization losses. The values are expressed in milligrams of nitrogen and percentage of total feed and sugar cane molasses inputs.

However, aside from the large portion of $\mathrm{N}$ present in the shrimp biomass, most of the $\mathrm{N}$ that entered the tanks remained in the dissolved form, while particulate $\mathrm{N}$ was of minor importance (Fig. 7). Most dissolved nitrogen was organic, indicating that the BFT system was very effective in diminishing the inorganic nitrogen species, especially the ammonium and nitrite forms that may be toxic for shrimp.

In systems without water renewal, phytoplankton and bacteria are responsible for the incorporation and/or transformation of ammonium, which helps maintain water quality. In this study, it was possible to identify the action of three different groups of microorganisms in the control of ammonium in the tanks. For example, from the beginning of the experiment to Day 9, the uptake of ammonium by phytoplankton was probably responsible for the low levels of this nutrient in the water because ammonium concentrations were the highest after the phytoplankton crash on Day 15 (Fig. 3).

Heterotrophic bacteria also played an important role in removing TAN when an additional 


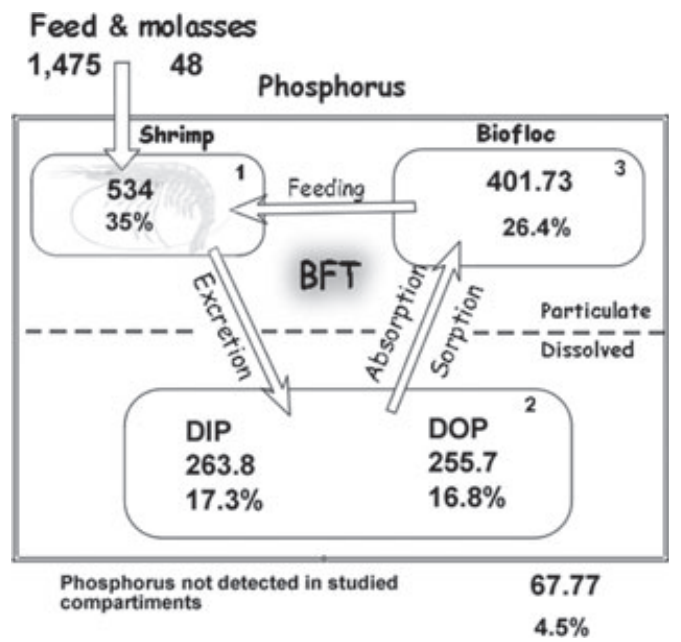

FIGURE 8. Phosphorus budget for Litopenaeus vannamei production. The inner boxes represent (1) shrimp, (2) the dissolved nitrogen pool, and (3) the particulate nitrogen pool (larger than $0.7 \mu \mathrm{m}$ ). The values outside the main rectangle represent the amount of phosphorus that was not measured in any of the compartments of the model. The values are expressed in milligrams of phosphorus and percentage of total feed and sugar cane molasses inputs.

energy source was available. The addition of $20 \mathrm{~g}$ of sugar cane molasses on Day 21 rapidly reduced ammonium concentrations from 0.7 to $0.14 \mathrm{mg} / \mathrm{L}$, indicating that heterotrophic bacteria quickly absorbed and immobilized TAN in the presence of a labile carbon source. However, a portion of the incorporated ammonium was released back into the water (Day 24) (Fig. 3). It is likely that the uptake of ammonium and carbon generated an increase in bacterial abundance that, in turn, was grazed by flagellates and ciliates. TAN production due to protozoan excretion has been considered an important nitrogen regeneration process in natural environments (Dolan 1997; Maguer et al. 1999). The same phenomenon may be occurring here, but this hypothesis remains to be tested.

Previous studies have highlighted the importance of heterotrophic bacteria in controlling TAN by their incorporation of nitrogen into cellular proteins (Avnimelech, 1999; Ebeling et al. 2006); however, the results obtained here demonstrate that nitrification may be more substantial for TAN removal than bacterial cell protein production. This hypothesis is supported by the large amount of nitrate measured at the end of the experiment compared to the low PN levels (Fig. 7). Despite the efficiency of nitrifying bacteria in removing TAN, this bacterial community took longer to initiate the uptake of ammonium from the water, probably due to their slow growth rate. Therefore, nitrification has been considered a poor TAN removal mechanism in aquaculture systems with high water exchange rates because the bacterial community is constantly changing (Burford et al. 2003; Ebeling et al. 2006). However, in a BFT system with little or no water replacement, a nitrifying bacterial community may be established with good results in terms of water quality. Therefore, nitrifying bacteria should be isolated and cultured for future inoculation in BFT culture systems.

In addition to TAN removal by microalgae and auto- and heterotrophic bacteria, denitrification and/or ammonium volatilization were also likely responsible for the elimination of $21.9 \%$ of the TN input. Although present in highly oxygenated water, the bioflocs can provide anaerobic microsites that could promote denitrification in a BFT system. Jørgensen (1977) described the presence of anaerobic sites in particles ranging from $100 \mu \mathrm{m}$ to a few millimeters of diameter, and Paerl (1984) estimated that anoxygenic microsites appear in structures, such as aggregates and biofilm. Ammonia volatilization may also play an important role in nitrogen removal when the $\mathrm{pH}$ exceeds 9 , in response to the depletion of $\mathrm{CO}_{2}$ from the solution by phytoplankton uptake (Hariyadi et al. 1994). However, in our study, $\mathrm{pH}$ values near 9 were only measured during the first 2 wk of the experiment when there was not enough TAN to generate significant ammonia volatilization. Therefore, we believe that most of the nitrogen losses in this study were due to denitrification.

The DON pool represented $31.25 \%$ of the total $\mathrm{N}$ input, comprising the main fraction other than that incorporated into the shrimp biomass. The high DON pool may be attributed to the leaching of uneaten feed, shrimp excretion, and feces (Burford and Williams 2001). Phytoplankton can also release significant 
amounts of free amino acids during photosynthesis (Rosenstock and Simon 2001). Bronk et al. (1994) reported that $90 \%$ of the nitrate uptake by phytoplankton growing in low light (as encountered in BFT systems) conditions was released as DON. Moreover, cell lyses caused by grazing of zooplankton and other microorganisms on phytoplankton ("sloppy feeding"), as well as viral infection, are other possible sources of DON in the BFT system (Moller 2007; Titelman et al. 2008). It is also likely that the heterotrophic community may have contributed to the DON pool through metabolite production by enzymes, mucilage, and humic-like substances. The production of these elements by bacteria appears to be enhanced when organic substrates are in excess (Tempest and Niejssel 1992).

Despite the fact that DON does not represent an immediate risk to raised shrimp, its presence may stimulate the growth of harmful algae inside the aquaculture systems and in the body of water that collects aquaculture effluents (Anderson et al. 2008). Jackson et al. (2003) were the first to show that DON, rather than TAN, was the main dissolved nitrogen form present in aquaculture wastewater. These authors also emphasized the need for specific nutrient recovery strategies directed to wastewater rich in DON.

Finally, the low levels of PN found in bioflocs $(1.4 \%$ of $\mathrm{TN})$ were quite surprising because several studies have demonstrated the importance of attached microbiota in the improvement of particle nutritious quality caused by an increase of protein levels (Decamp et al. 2002; Abreu et al. 2007; Ballester et al. 2010). Low PN/TSS ratios at the end of the experiment, however, suggest that at this stage, bioflocs did not represent an important protein source for shrimp. Silva et al. (2008) previously found a direct relationship between the amount of diatoms and the protein content in biofilm present in net cages used for shrimp culture. Therefore, it is possible that the reduced levels of $\mathrm{PN}$ at the end of the experiment are related to the decreased abundance of phytoplankton, which occurred after experimental Day 20.

It was observed in this study that shrimp biomass incorporated $35 \%$ of the total phosphorous input (Fig. 8). This finding is worth note because it greatly exceeds the levels found in other intensive and semi-intensive culture systems in which $\mathrm{P}$ incorporation in shrimp biomass varied between 6 and $13 \%$ of the P input (Páez-Osuna et al. 1997; FungeSmith and Briggs 1998; Thakur and Lin 2003; Casillas-Hernández et al. 2006). However, large amounts of phosphorus remained in the system in dissolved (17.3\% DIP and 16.8\% DOP) and particulate (biofloc, 26.4\%) forms (Fig. 8).

The BFT system is designed to use little or no water exchange, hampering the elimination of phosphorus through water renewal. Moreover, phosphorus cannot be lost atmospherically, unlike nitrogen (denitrification and ammonia volatilization). Therefore, the increase of dissolved inorganic and organic phosphorus concentrations is expected for any zero-water exchange culture system.

TABLE 1. Nitrogen and phosphorus waste compared to shrimp production (tons) for different stocking densities and management systems.

\begin{tabular}{lcccc}
\hline Species & Density & Nitrogen $(\mathrm{kg} / \mathrm{ton})$ & Phosphorus (kg/ton) & References \\
\hline Litopenaeus vannamei & Super-intensive & 20 & 4,1 & This study \\
Penaeus monodon & Intensive & 72 & - & Jackson et al. (2003) \\
P. monodon & Intensive & 81 & 44 & Funge-Smith and Briggs (1998) \\
P. monodon & Intensive & 112 & 31 & Robertson and Phillips (1995) \\
P. monodon & Intensive & 72 & - & Jackson et al. (2003) \\
L. vannamei & Semi-intensive & 73 & 12 & Casillas-Hernández et al. (2006) \\
L. vannamei & Semi-intensive & 36 & 12 & Páez-Osuna et al. (1997) \\
L. vannamei & Semi-intensive & 29 & 12 & Teichert-Codington et al. (2000) \\
\hline
\end{tabular}


Phosphorus toxicity is virtually nonexistent. However, high concentrations of phosphate should be avoided because this may lead to the occurrence of harmful cyanobacteria blooms in culture systems (Smith 1983; Anderson et al. 2002).

Similar to that observed for DON, some measures must be applied to avoid increased loads of dissolved and PP in BFT systems. In addition, measures should be taken to eliminate high phosphorus contents in the BFT post-crop wastewater discharge. Despite the high levels of DON and dissolved and PP, this study demonstrates that the culture of L. vannamei using BFT generates much smaller nutrient loads in comparison to other shrimp species and aquaculture systems. According to our analysis, approximately $20 \mathrm{~kg} \mathrm{~N}$ and $4.1 \mathrm{~kg} \mathrm{P}$ are generated for each ton of shrimp produced in the BFT system. These values are considerably smaller than those measured in other systems with different shrimp species and densities (Table 1). Therefore, the smaller $\mathrm{N}$ and $\mathrm{P}$ loads in the rearing water of the BFT system are due to the presence of bioflocs, which recycle and absorb the surplus nutrients. Once in the particulate pool, nutrients may be exploited by the shrimp, thereby increasing the retention of $\mathrm{N}$ and $\mathrm{P}$ in this compartment.

In summary, this study has displayed the importance of biofloc microbiota in water quality maintenance. The results also demonstrate the necessity of water treatment for DON and dissolved and PP removal that may represent a problem for shrimp production using BFT over longer periods. Further studies should consider the efficiency of possible water treatment to reuse water in the BFT system.

\section{Literature Cited}

Abreu, P. C., E. L. C. Ballester, C. Odebrecht, W. Wasielesky Jr., R. O. Cavalli, W. Granéli, and A. M. Anésio. 2007. Importance of biofilm as food source for shrimp (Farfantepenaeus paulensis) evaluated by stable isotopes (d13C and d15N). Journal of Experimental Marine Biology and Ecology 347:88-96.

Anderson, D. M., P. M. Glibert, and J. M. Burkholder. 2002. Harmful algal blooms and eutrophication nutrient sources, composition, and consequences. Estuaries 25:704-726.
Anderson, D., J. Burkholder, W. Cochlan, P. Gilbert, C. Gobler, C. Heil, R. Kudela, M. Parsons, J. Rensel, D. Townsend, V. Trainer, and G. Vargo. 2008. Harmful algal blooms and eutrophication: examining links from selected regions of the United States. Harmful Algae 8:39-53.

AOAC. 1995. Official methods of analysis of the Association of Official Analytical Chemists International, 16th edition. Association of Official Analytical Chemists, Arlington, Virginia, USA.

Avnimelech, Y. 1999. Carbon/nitrogen ratio as a control element in aquaculture systems. Aquaculture 176:227-235.

Avnimelech, Y. 2006. Bio-filters: the need for a new comprehensive approach. Aquaculture Research 34:172-178.

Ballester, E. L. C., W. Wasielesky Junior, R. O. Cavalli, and P. C. Abreu. 2007. Nursery of the pink shrimp Farfantepenaeus paulensis in cages with artificial substrates: biofilm composition and shrimp performance. Aquaculture 269:355-362.

Ballester, E., P. C. Abreu, R. Cavalli, M. Emerenciano, L. Abreu, and W. Wasielesky. 2010. Effect of practical diets with different protein levels on the performance of Farfantepenaeus paulensis juveniles nursed in a zero exchange suspended microbial flocs intensive system. Aquaculture Nutrition 16(2):163-172.

Boyd, C. E. and J. W. Clay. 1998. Shrimp Aquaculture and the Environment. Scientific American 278:58-65.

Bronk, D. A., P. M. Glibert, and B. B. Waerd. 1994. Nitrogen uptake, dissolved organic nitrogen release, and new production. Science 265:843-1846.

Browdy, C. L., D. Bratvold, A. D. Stokes, and R. P. McIntosh. 2001. Perspectives on the application of closed shrimp culture systems. Pages 20-34 in C. L. Browdy and D. E. Jory, editors. The New Wave, Proceedings of the Special Session on Sustainable Shrimp Culture, Aquaculture 2001. The World Aquaculture Society, Baton Rouge, Louisiana, USA.

Burford, M. A. and K. C. Williams. 2001. The fate of nitrogenous waste from shrimp feeding. Aquaculture 198:79-93.

Burford, M. A., P. J. Thompson, R. P. Mcintosh, R. H. Bauman, and D. C. Pearson. 2003. Nutrient and microbial dynamics in high-intensity, zero-exchange shrimp ponds in Belize. Aquaculture 219:393-411.

Burford, M. A., P. J. Thompson, R. P. McIntosh, R. H. Bauman, and D. C. Pearson. 2004. The contribution of flocculated material to shrimp (Litopenaeus vannamei) nutrition in a high-intensity, zero-exchange system. Aquaculture 232:525-537.

Casillas-Hernández, R., F. Magallón-Barajas, G. Portillo-Clarck, and F. Páez-Osuna. 2006. Nutrient mass balances in semi-intensive shrimp ponds from Sonora, Mexico using two feeding strategies: trays and mechanical dispersal. Aquaculture 258:289-298.

Decamp, O., L. Conquest, I. Foster, and A. Tacon. 2002. The nutrition and feeding of marine shrimp within 
zero-water exchange aquaculture production system: role of eukaryotic microorganisms. Pages 79-86 in C. S. Lee and P. Obryen, editors. Microbial approaches to aquatic nutrition within environmentally sound aquaculture production systems. World Aquaculture Society, Baton Rouge, Louisiana, USA.

Dolan, J. 1997. Phosphorus and ammonia excretion by planktonic protests. Marine Geology 139:109-122.

Ebeling, J. M., M. B. Timmons, and J. J. Bisogni. 2006. Engineering analysis of the stoichiometry of photoautotrophic, autotrophic, and heterotrophic removal of ammonia-nitrogen in aquaculture systems. Aquaculture 257:346-358.

FAO (Food and Agriculture Organization of the United Nation). 2010. SOFIA - The State of World Fisheries and Aquaculture. Accessed December 30, 2012, at http://www.fao.org/docrep/013/i1820e/i1820e00.htm.

Funge-Smith, S. J. and M. R. P. Briggs. 1998. Nutrient budgets in intensive shrimp ponds: implications for sustainability. Aquaculture 164:117-133.

Hariyadi, S., C. S. Tucker, J. A. Steeby, and M. van der Ploeg, and C. E. Boyd. 1994. Environmental conditions and channel catfish Ictalurus punctatus production under similar pond management regimes in Alabama and Mississippi. Journal of the World Aquaculture Society 25:236-249.

Jackson, C., N. Preston, P. J. Thompson, and M. Burford. 2003. Nitrogen budget and effluent nitrogen components at an intensive shrimp farm. Aquaculture 218:397-411.

Jørgensen, B. B. 1977. Bacterial sulfate reduction within reduced microniches of oxidized marine sediments. Marine Biology 41:7-17.

Jory, E. J., T. R. Cabrera, D. M. Dugger, D. Fegan, P. G. Lee, A. L. Lawrence, C. J. Jackson, R. P. Mcintosh, and J. Castaneda. 2001. A global review of shrimp feed management: status and perspectives. Pages 104-152 in C. L. Browdy, editor. The New Wave, Proceedings of the Special Session on Sustainable Shrimp Culture, Aquaculture 2001. The World Aquaculture Society, Baton Rouge, Louisiana, USA.

Kibria, G., D. Nugegoda, P. Lam, and R. Fairclough. 1996. Aspects of phosphorus pollution from aquaculture. NAGA, The ICLARM Quarterly 19:20-24.

Lacerda, L. D., A. G. Vaisman, L. P. Maia, C. A. R. Silva, and E. M. S. Cunha. 2006. Relative importance of nitrogen and phosphorus emissions from shrimp farming and other anthropogenic sources for six estuaries along the NE Brazilian coast. Aquaculture 253:433-446.

Maguer, J.-F., S. L'Helguen, C. Madec, and P. Le Corre. 1999. Seasonal patterns of ammonium regeneration from size-fractionated microheterotrophs. Continental Shelf Research 19:1755-1770.

Martin, J. M., Y. Veran, O. Guelorget, and D. Pham. 1998. Shrimp rearing: stocking density, growth, impact on sediment, waste output and their relationships studied through the nitrogen budget in rearing ponds. Aquaculture 164:35-149.
Moller, F. E. 2007. Production of dissolved organic carbon bysloppy feeding in the copepods Acartia tonsa, Centropages typicus, and Temora longicornis. Limnology and Oceanography 52:79-84.

Montoya, R. A., A. L. Lawrence, W. E. Grand, and M. Velasco. 2000. Simulation of phosphorus dynamics in an intensive shrimp culture system: effects of feed formulations and feeding strategies. Ecological Modelling 129:131-142.

Moss, S. M. 1999. Biosecure shrimp production: emerging technologies for a maturing industry. Global Aquaculture Advocate 2:50-52.

Naylor, R. L., R. J. Goldburg, J. H. Primavera, N. Kautsky, M. C. M. Beveridge, J. Clay, C. Folke, J. Lubchenco, H. Mooney, and M. Troell. 2000. Effect of aquaculture on world fish supplies. Nature 405:1017-1024.

Paerl, H. W. 1984. Alteration of microbial metabolic activities in association with detritus. Bulletin of Marine Science 35:393-408.

Páez-Osuna, R., A. C. Guerrero-Galvan, A. C. Ruiz-Hernandez, and R. Espinoza-Ângulo. 1997. Fluxes and mass balances of nutrients in a semiintensive shrimp farm in North-Western Mexico. Marine Pollution Bulletin 32:290-297.

Robertson, A. and M. Phillips. 1995. Mangroves as filters of shrimp pond effluent: predictions and biogeochemical research needs. Hydrobiologia 295:311-321.

Rosenstock, B. and M. Simon. 2001. Sources and sinks of dissolved free amino acids and protein in a large and deep mesotrophic lake. Limnology and Oceanography 46:644-654.

Sena, S. S., T. T. N. Thuy, W. A. Nigel, and S. A. Upali. 2006. An evaluation of the role and impacts of alien finfish in Asian inland aquaculture. Aquaculture Research 37:1-17.

Silva, C. F., E. Ballester, J. Monserrat, L. Geracitano, W. Wasielesky Jr., and P. C. Abreu. 2008. Contribution of microorganisms to the biofilm nutritional quality: protein and lipid contents. Aquaculture Nutrition 14:507-514.

Smith, V. H. 1983. Low nitrogen to phosphorus ratios favor dominance by blue-green algae in lake phytoplankton. Science 221:669-671.

Strickland, J. L. H. and T. R. Parsons. 1972. A practical handbook of seawater analysis. Bulletin of the Fisheries Research Board of Canada, Ottawa, Canada.

Tacon, A. G. J., J. Cody, L. Conquest, S. Divakaran, I. P. Forster, and O. Decamp. 2002. Effect of culture system on the nutrition and growth performance of Pacific white shrimp Litopenaeus vannamei (Boone) fed different diets. Aquaculture Nutrition 8:121-137.

Teichert-Codington, D., D. Martinez, and E. Ramírez. 2000. Partial nutrient budget for semi-intensive shrimp farms in Honduras. Aquaculture 190:139-154.

Tempest, W. and M. Niejssel. 1992. Physiological and energetic aspects of bacterial metabolite overproduction. FEMS Microbiology 64:91-99. 
Thakur, D. P. and K. C. Lin. 2003. Water quality and nutrient budget in closed shrimp (Penaeus monodon) culture systems. Aquacultural Engineering 27:159-176.

Thoman, E. S., E. D. Ingall, A. D. Davis, and R. C. Arnold. 2001. A nitrogen budget for a closed, recirculating mariculture system. Aquacultural Engineering 24:195-211.

Titelman, J., L. Riemann, K. Holmfeld, and T. Nielsen. 2008. Copepod feeding stimulates bacterioplankton activities in a low phosphorus system. Aquatic Biology 2:131-141.

Tovar, A., C. Moreno, M. P. Manuel-Vez, and M. Garcia-Vargas. 2000. Environmental impacts of intensive aquaculture in marine waters. Water Research 34:334-342.

UNESCO 1983. Chemical methods for use in marine environmental monitoring. Pages $29-36$ in Manual and guides 12. Intergovernmental Oceanographic Commission, Paris, France.

Valderrama, J. C. 1981. The simultaneous analysis of total nitrogen and total phosphorus in natural waters. Marine Chemistry 10:109-122.
Van Wyk, P. and J. Scarpa. 1999. Water quality and management. Pages 128-138 in P. Van Wyk et al., editors. Farming marine shrimp in recirculating freshwater systems. Florida Department of Agriculture and Consumer Services, Tallahassee, Florida, USA.

Weirich, C. R., C. L. Browdy, B. J. Bratvold, and A. D. Stokes. 2002. Preliminary characterization of a prototype minimal exchange super-intensive shrimp production system. Pages 255-270 in T. T. Rakestraw, L. S. Douglas and G. J. Flick, editors. Proceedings of the IVth International Conference on Recirculating Aquaculture. Virginia Polytechnic Institute and State University, Roanoke, Virginia, USA.

Welschmeyer, N. A. 1994. Fluorometric analysis of chlorophyll- $a$ in the presence of chlorophyll- $b$ and phaeopigments. Limnology and Oceanography 39:1985-1992.

Wickins, J. F. 1976. The tolerance of warm-water prawns to recirculated water. Aquaculture 9:19-37. 